Kouwenhoven, P.S.C., Raijmakers, N.J.H., Delden, J.J.M. van, Rietjens, J.A.C., Schermer, M.H.N., Thiel, G.J.M.W. van, Trappenburg, M.J., Vathorst, S. van de, Vegt, B.J. van der, Vezzeni, 7 C., Weyers, H., Tol, D.G. van, Heide, A. van der. Opinions of health care professionals and the ive public after eight years of euthanasia legislation in the Netherlands: a mixed methods approach. Palliative Medicine: 2013, 27(3), 273-280

\begin{tabular}{|l|l|}
$\begin{array}{l}\text { Postprint } \\
\text { Version }\end{array}$ & 1.0 \\
\hline Journal website & http://pmj.sagepub.com/content/27/3/273.long \\
\hline Pubmed link & http://www.ncbi.nlm.nih.gov/pubmed/22695742 \\
\hline DOI & $10.1177 / 0269216312448507$
\end{tabular}

This is a NIVEL certified Post Print, more info at http://www.nivel.eu

\title{
Opinions of health care professionals and the public after eight years of euthanasia legislation in the Netherlands: A mixed methods Approach
}

Pauline SC Kouwenhoven* Julius Center, University Medical Center Utrecht, The Netherlands

Natasja JH Raijmakers* Department of Public Health, Erasmus MC, The Netherlands;

Department of Medical Oncology, Erasmus MC, The Netherlands

Johannes JM van Delden Julius Center, University Medical Center Utrecht, The Netherlands Judith AC Rietjens Department of Public Health, Erasmus MC, The Netherlands

Maartje HN Schermer Department of Ethics and Philosophy of Medicine, Erasmus MC, The Netherlands

Ghislaine JMW van Thiel Julius Center, University Medical Center Utrecht, The Netherlands Margo J Trappenburg Utrecht School of Governance, Utrecht University, The Netherlands

Suzanne van de Vathorst Department of Ethics and Philosophy of Medicine, Erasmus MC, The Netherlands

Bea J van der Vegt Department of Health Sciences, University of Groningen, The Netherlands

Cristiano Vezzoni Department of Health Sciences, University of Groningen, The

Netherlands; Department of Sociology and Social Research, University of Trento, Italy Heleen Weyers Department of Health Sciences, University of Groningen, The Netherlands; Department of Legal Theory, University of Groningen, The Netherlands

Donald G van Tol Department of Health Sciences, University of Groningen, The Netherlands Agnes van der Heide Department of Public Health, Erasmus MC, The Netherlands

\begin{abstract}
Background: The practice of euthanasia and physician-assisted suicide (PAS) in the Netherlands has been regulated since 2002 by the Euthanasia Act. In the ongoing debate about the interpretation of this Act, comparative information about the opinions of the different stakeholders is needed.

Aim: To evaluate the opinions of Dutch physicians, nurses and the general public on the legal requirements for euthanasia and PAS.

Design: A cross-sectional survey among Dutch physicians and nurses in primary and secondary care and members of the Dutch general public, followed by qualitative interviews among selected respondents. The participants were: 793 physicians, 1243 nurses and 1960 members of the general public who completed the questionnaire; 83 were interviewed.
\end{abstract}


Kouwenhoven, P.S.C., Raijmakers, N.J.H., Delden, J.J.M. van, Rietjens, J.A.C., Schermer, M.H.N., Thiel, G.J.M.W. van, Trappenburg, M.J., Vathorst, S. van de, Vegt, B.J. van der, Vezzeni, 7 C., Weyers, H., Tol, D.G. van, Heide, A. van der. Opinions of health care professionals and the public after eight years of euthanasia legislation in the Netherlands: a mixed methods approach. Palliative Medicine: 2013, 27(3), 273-280

Results: Most respondents agreed with the requirement of a patient request (6488\%) and the absence of a requirement concerning life expectancy (48-71\%). PAS was thought acceptable by $24-39 \%$ of respondents for patients requesting it because of mental suffering due to loss of control, chronic depression or early dementia. In the case of severe dementia, one third of physicians, $58 \%$ of nurses and $77 \%$ of the general public agreed with performing euthanasia based on an advance directive. Interviewees illustrated these findings and supported the Act. Conclusions: Health care professionals and the general public mostly support the legal requirements for euthanasia and PAS. The law permits euthanasia or PAS for mental suffering but this possibility is not widely endorsed. The general public is more liberal towards euthanasia for advanced dementia than health care professionals. We conclude that there is ample support for the law after eight years of legal euthanasia.

\section{INTRODUCTION}

Legalizing euthanasia and physician-assisted suicide (PAS) is an issue for debate in many countries. The practice of euthanasia and PAS in the Netherlands has been regulated since 2002 in the Dutch Euthanasia Act (Termination of Life on Request and Assisted Suicide Act). The Act formulates criteria of due care. Only if a physician performs euthanasia or PAS according to these criteria, will his actions not be punishable. The criteria of due care require that the physician be convinced that (1) there is a voluntary and well-considered request from the patient, (2) the patient is suffering unbearably without prospect of improvement, (3) the patient is informed about his situation and prospects, (4) there are no reasonable alternatives to relieve suffering, (5) an independent physician must be consulted and (6) euthanasia or PAS is performed with due medical care and attention. The act does not entail a legal right to euthanasia or PAS nor does it contain a limit on a patient's life expectancy. Physicians have to report euthanasia or PAS to one of five regional multidisciplinary review committees.

These review committees assess whether or not the physician has acted in accordance with the criteria of due care. The judgements of the review committees and case law thus provide a definite fulfilment of these criteria. Dutch opinions have been studied before. ${ }^{1}$ In previous research as well as in the ongoing societal debate about the interpretation of this Act, growing divergence is claimed between the knowledge and opinions of health care professionals and the general public. ${ }^{2}$ Comprehensive current comparative information about the opinions of the different stakeholders is lacking and is needed.

The aim of this study was to evaluate opinions about the law among Dutch health care professionals and the general public after eight years of official euthanasia legislation. The following research question was addressed: What are the opinions of physicians, nurses and the general public in the Netherlands on legal requirements for euthanasia and PAS? 
Kouwenhoven, P.S.C., Raijmakers, N.J.H., Delden, J.J.M. van, Rietjens, J.A.C., Schermer, M.H.N., Thiel, G.J.M.W. van, Trappenburg, M.J., Vathorst, S. van de, Vegt, B.J. van der, Vezzeni, 7 C., Weyers, H., Tol, D.G. van, Heide, A. van der. Opinions of health care professionals and the public after eight years of euthanasia legislation in the Netherlands: a mixed methods approach. Palliative Medicine: 2013, 27(3), 273-280

\section{METHODS}

\section{Design and population}

We conducted a cross-sectional survey among physicians, nurses and members of the Dutch general public, followed by a qualitative interview study among a selection of the respondents. Regarding ethical approval, according to Dutch law, this kind of observational study is exempt from ethical review.

\section{Survey.}

A questionnaire was sent to a random sample of 1250 medical specialists of internal medicine, cardiology, pulmonology, neurology and surgery, 500 general practitioners and 250 elderly care physicians. Addresses were taken from the Royal Dutch Medical Association (KNMG), the Dutch Institute for Research of Health Care (NIVEL) and the Dutch Association of Elderly Care Physicians (Verenso), respectively. Respondents had to: (1) be working in the Netherlands, (2) have at least two years of experience in their current specialty, and (3) if retired, have been retired no longer than two years prior to participation or be under 67 years of age. The questionnaire could be completed by mail or electronically over a four-month period (January through May 2010). Two reminders were sent.

During the same period, a similar questionnaire was offered to nurses by various professional nursing organisations in the Netherlands, through websites and journals. This questionnaire was freely accessible on the internet. To be eligible for the study, respondents had to: (1) be a registered nurse, (2) be working as such for at least two years, and (3) be working in the Netherlands. The questionnaire started with three selective questions. If respondents did not meet the criteria, they were automatically excluded from completing the questionnaire.

A comparable online questionnaire was offered to an established panel of members of the Dutch general public (CentERdata, University of Tilburg, The Netherlands). This panel comprises a random sample of postal codes in the Netherlands. Multiple measures are in place to avoid selection bias of this panel, such as guaranteeing accessibility for all selected households by providing all selected members of the panel with a free tool that enables response by internet or television. During the survey period (December 2009-February 2010), 2503 persons were active members of the total panel. We only included respondents aged 18 or over.

\section{Interview study.}

At the end of the questionnaire, we invited respondents to participate in an interview and if they consented, to provide us with their personal contact details. Anonymity was indicated to the respondents to be lost in this case. For all groups, based on their responses to the questionnaires, we selected candidates who were willing to participate in in-depth interviews. We used the method of purposive sampling ${ }^{3}$ in order to guarantee a wide range of different opinions. We selected respondents with and without experience with euthanasia and with different attitudes towards euthanasia (liberal, conservative or neutral).

Besides this, we strived for a balanced distribution of age, education and gender. We selected 25 respondents per subgroup, 125 respondents in total. We continued enrolling subjects for interviews in each group until we had achieved conceptual saturation for each group. 
Kouwenhoven, P.S.C., Raijmakers, N.J.H., Delden, J.J.M. van, Rietjens, J.A.C., Schermer, M.H.N., Thiel, G.J.M.W. van, Trappenburg, M.J., Vathorst, S. van de, Vegt, B.J. van der, Vezzeni, 7 C., Weyers, H., Tol, D.G. van, Heide, A. van der. Opinions of health care professionals and the public after eight years of euthanasia legislation in the Netherlands: a mixed methods approach. Palliative Medicine: 2013, 27(3), 273-280

\section{Data collection}

The questionnaires involved questions on respondent characteristics as well as on experiences and opinions regarding euthanasia and PAS. Statements on euthanasia were rated using a five-point Likert scale, ranging from 'totally agree' to 'totally disagree'. Respondents were also asked about their opinions regarding unbearable suffering as a reason for euthanasia and PAS, presented in different vignettes (Box 1(a)-(f)).

The questionnaire was pretested for length, comprehensibility and feasibility for online use among 10 physicians, 8 nurses and 14 members of the general public. These pilots resulted in small adjustments in the questionnaire.

Interviews were conducted by five researchers (PK, NR, DvT, BvdV and HW) and two medical students. There was no relationship between the interviewees and the interviewers prior to the study and no personal characteristics of the interviewers were known to the interviewees. Most interviews with professionals were conducted at their working place and with the public in the privacy of their homes. Before the start of the interview, the voluntary character and confidentiality of participation were emphasized. The one-hour interviews were semi-structured with use of an interview guideline with open questions and topics. First, we asked about the respondents' association with the term 'euthanasia'. To explore opinions about euthanasia further, we asked what the participant would say to a foreign colleague (for professionals) or a foreign tourist (for members of the general public) about Dutch euthanasia practice and how it is regulated. The interviewees were asked to reflect on some of the vignettes that were used in the questionnaires. Finally, personal experiences (if any) with (requests for) euthanasia were addressed. The interview guideline was tested for length and comprehensibility. This led to some minor adjustments. Because several researchers performed the interviews, the use of the interview guideline was discussed and practised in detail during training for all interviewers.

\section{Statistical analysis}

The quantitative data were analyzed with descriptive statistics using SPSS 17.0. Valid percentages are presented in the tables; missing values did not exceed $10 \%$. Opinions on euthanasia and PAS were recoded and reported in three categories: 'agree', 'neutral' and 'not agree'. For each group of physicians a weight factor was calculated in order to make the results representative for all physicians in the Netherlands.

All interviews have been transcribed verbatim and were analyzed with content analysis using Atlas.ti version 6.1.1.

Two researchers per group coded all interviews, using a uniform code tree that was developed and agreed on by all interviewers on the basis of the results. Transcripts were not returned to the interviewees.

\section{RESULTS}

\section{Characteristics of respondents}

The numbers of respondents were 793 for physicians (response rate 41\%), 1243 for nurses and 1960 for the general public (response rate 78\%). The mean age was 51 
Kouwenhoven, P.S.C., Raijmakers, N.J.H., Delden, J.J.M. van, Rietjens, J.A.C., Schermer, M.H.N., Thiel, G.J.M.W. van, Trappenburg, M.J., Vathorst, S. van de, Vegt, B.J. van der, Vezzeni, 7 C., Weyers, H., Tol, D.G. van, Heide, A. van der. Opinions of health care professionals and the ive public after eight years of euthanasia legislation in the Netherlands: a mixed methods approach. Palliative Medicine: 2013, 27(3), 273-280

years for physicians, 53 years for the general public and 44 years for nurses. Twothirds of the physicians, $10 \%$ of nurses and $54 \%$ of the general public were male; $81 \%$ of nurses and $39 \%$ of the general public respondents were highly educated. Most physicians and nurses had experience with a request for euthanasia or PAS in the last five years. Most respondents of the general public had no such experience (Table 1).

In total 83 interviews were conducted until saturation was reached; 49 with physicians, 18 with nurses, and 16 with members of the general public.

\section{Opinions on the Dutch Euthanasia Act}

Broad support for the Dutch Euthanasia Act was displayed among interviewees, irrespective of their personal attitude.

Interviewees based their approval mainly on two arguments.

First, euthanasia can be morally right because it is the last resort to end unbearable suffering without prospect of improvement. Second, autonomy is highly valued (Box 2.1).

Even principal opponents among the interviewees often defended the Act against allegedly misinformed (foreign) critics (Box 2.2). Also interviewees considered its function as a safeguard to both careful and transparent practice to be an important benefit of the Act (Box 2.3). Furthermore, some physicians experienced the Act as a helping hand in making decisions that they experience as highly demanding. Some felt that it could be used as a shield against patients who claim euthanasia as their right (Box 2.4).

\section{Opinions of health care professionals on legal requirements}

In our survey, almost two-thirds of physicians (56\%) and more than one-third of nurses (36\%) agreed with the current absence of a right to euthanasia and PAS (Table 2). A majority of physicians (71\%) and nurses (64\%) agreed that euthanasia and PAS should not be limited to patients who have a life expectancy of only several weeks. A vast majority of physicians (88\%) and nurses (77\%) agreed with the need for a patient request.

\section{[BOX 1]}

Reviewing a vignette of a cancer patient suffering from loss of control and severe pain, $77 \%$ of physicians and $49 \%$ of nurses personally agreed with the performance of PAS (Box 1, Table 3). If in the same vignette physical symptoms were absent, fewer professionals agreed (36-37\%). A minority of professionals agreed with providing PAS in vignettes of a patient with chronic depression (35-36\%) or early dementia (28-31\%). One-third of physicians (33\%) and almost two-thirds of nurses (58\%) agreed with performing euthanasia in a vignette of a patient with advanced dementia based on a written advance directive. Almost two-thirds of professionals disagreed (64-66\%) with PAS in the case of being tired of living.

In reviewing some of the same vignettes during the interviews, professionals often considered physical symptoms without prospect of improvement as a necessary part of unbearable suffering. Some professionals felt it to be difficult to empathize with patients requesting euthanasia due to mental suffering. Also the absence of the terminal phase was sometimes seen as problematic. 
Kouwenhoven, P.S.C., Raijmakers, N.J.H., Delden, J.J.M. van, Rietjens, J.A.C., Schermer, M.H.N., Thiel, G.J.M.W. van, Trappenburg, M.J., Vathorst, S. van de, Vegt, B.J. van der, Vezzeni, 7 C., Weyers, H., Tol, D.G. van, Heide, A. van der. Opinions of health care professionals and the public after eight years of euthanasia legislation in the Netherlands: a mixed methods approach. Palliative Medicine: 2013, 27(3), 273-280

\section{Opinions of the general public on legal requirements}

Almost a quarter of the general public (23\%) agreed with the current absence of a right to euthanasia and PAS (Table 2).

Two-thirds of the general public (64\%) agreed with the need for a request of the patient. Almost half of respondents (48\%) agreed with the absence of a limitation of euthanasia to patients who have a life expectancy of only several weeks.

The majority of the general public (65\%) personally agreed with PAS in the vignette of a cancer patient suffering from loss of control and severe pain (Box 1, Table 3). Seventy-seven percent did so in a patient with advanced dementia who had completed a written advance euthanasia directive. Reviewing other vignettes of mental suffering, a minority of the general public agreed with PAS. In the cases of mental suffering from loss of control due to cancer (without severe pain), chronic depression or early dementia, respectively 39\%, 28\% and 24\% agreed with PAS. Furthermore a minority agreed in case of suffering due to being tired of living (26\%). In the interviews respondents related unbearable suffering primarily to physical suffering. In case of mental suffering interviewees found it difficult to assess the request for PAS and would like to explore other solutions, such as counselling for the patient.

\section{[TABLE 1]}

\section{INTERPRETATION}

Our study shows support for the Dutch Euthanasia Act both among health care professionals and in wider society. Major arguments for this support are the possibility of relief of unbearable suffering and respect for the patient's autonomy. Moreover the Act safeguards careful and transparent practice. The majority of the general public is in favour of a (currently non-existing) right to euthanasia. However, most professionals and members of the general public seem to be more conservative regarding the boundaries for euthanasia or PAS than the Act.

Both professionals and members of the general public tend to consider suffering as unbearable and qualifying for assistance in dying particularly in the presence of physical symptoms. They are more reticent about early dementia, depression and being tired of living. This is in line with previous studies in which more variation in the acceptance of euthanasia and PAS was found among health care professionals for non-physical as compared to physical suffering. ${ }^{4,5}$ An exception is advanced dementia. In a case of a patient with advanced dementia who had a written advance request for euthanasia, a majority of the general public and nurses agreed with granting this request, but only a minority of physicians did. Another study among elderly care physicians and relatives of people with dementia who had an advance directive for euthanasia also found them to be reticent in adhering to advance directives for euthanasia. ${ }^{6}$ Physicians have become more accepting over time, ${ }^{2}$ but variance in views on the admissibility of euthanasia in a case of advanced-stage dementia between physicians, nurses and the general public has been demonstrated elsewhere too. ${ }^{7,8}$ Although all parties seem to be guided by the best interest of the patient, different responsibilities in end-oflife decision-making may play a role here. The fact that performing euthanasia is solely allowed for physicians and has a clear 
Kouwenhoven, P.S.C., Raijmakers, N.J.H., Delden, J.J.M. van, Rietjens, J.A.C., Schermer, M.H.N., Thiel, G.J.M.W. van, Trappenburg, M.J., Vathorst, S. van de, Vegt, B.J. van der, Vezzeni, 7 C., Weyers, H., Tol, D.G. van, Heide, A. van der. Opinions of health care professionals and the public after eight years of euthanasia legislation in the Netherlands: a mixed methods approach. Palliative Medicine: 2013, 27(3), 273-280

emotional impact on them ${ }^{9}$ may explain their reticence. Euthanasia for a patient in an advanced stage of dementia may involve an even greater emotional burden due to the fact that the person receiving it is not capable of confirming his wish anymore.

\section{[BOX 2] [TABLE 2] [TABLE 3]}

The general support for the Dutch Euthanasia Act is in line with an international trend towards public acceptance of euthanasia. ${ }^{10,11}$ Also, earlier studies have shown a small number of opponents among the Dutch general public. ${ }^{12}$ However, international professional acceptance of euthanasia varies widely. ${ }^{13-20}$ The strengths of our study include the large and high quality nationwide samples of physicians and the general public. Our mixed-methods approach gives more in-depth understanding of the underlying reasoning of our quantitative data and makes a more accurate interpretation of quantitative results possible. Moreover, the questionnaires were highly comparable between all groups of respondents and consisted of a combination of different types of questions and presentations including statements and vignettes. Vignettes are widely used in decision-making research ${ }^{21}$ and have shown their value. ${ }^{22}$ However, it should be taken into account that respondents could have based their judgements on different aspects of the vignettes.

Our study has some other limitations as well. No random sample was available for nurses, due to the absence of a national registry for nurses in the Netherlands.

Therefore we aimed at reaching as many nurses as possible by open invitation. For all groups, possible selection bias should be taken into account. For physicians, the response rate was rather low (41\%). However, the results were made representative for all physicians from the studied groups by applying a weight factor. It is possible that especially physicians and nurses with experience and affinity with the discussion about euthanasia have participated in this study.

This should be taken into account when interpreting the results, but is not likely to alter the direction of our findings.

Since the interview study showed even physicians who have principled objections against euthanasia to be content with the Act, it can be concluded that there is ample support for the law in this group. Moreover, the number of opponents of euthanasia and physician-assisted suicide is comparable to earlier studies in the Netherlands. Therefore we think that bias is not very likely.

Additionally, despite a good response rate among the general public, respondents were not fully representative of the Dutch population; they were slightly older, more often male, higher educated and more often sharing a household.

Also migrants were underrepresented. This latter issue is known to be the case in nationwide surveys on other topics too. To assess their opinions purposive sampling should be considered. Furthermore, the questionnaires were rather extensive, which resulted in a substantial number of missing answers at the end of the questionnaires. In conclusion, health care professionals, as well as the general public, mostly support the legal requirements for euthanasia and PAS. The law permits euthanasia or PAS for mental suffering, but this principle is not widely endorsed. There is one exception. The majority of the general public and nurses agree with the possibility of euthanasia in advanced dementia. 
Kouwenhoven, P.S.C., Raijmakers, N.J.H., Delden, J.J.M. van, Rietjens, J.A.C., Schermer, M.H.N., Thiel, G.J.M.W. van, Trappenburg, M.J., Vathorst, S. van de, Vegt, B.J. van der, Vezzeni, 7 C., Weyers, H., Tol, D.G. van, Heide, A. van der. Opinions of health care professionals and the rive public after eight years of euthanasia legislation in the Netherlands: a mixed methods approach. Palliative Medicine: 2013, 27(3), 273-280

Physicians are more reticent. We conclude that the Dutch Euthanasia Act can count on ample support both among health care professionals and within general society.

\section{ACKNOWLEDGEMENTS}

The authors would like to thank all respondents who participated in this study of the KOPPEL consortium. KOPPEL is a study on Knowledge and Opinions of Public and Professionals on End-of- Life decisions.

\section{FUNDING}

This study was supported by a grant from the Ministry of Health, Welfare and Sports. The sponsors approved the study design, but were not involved in the collection, analysis and interpretation of data.

\section{CONFLICT OF INTEREST}

The authors declare that there is no conflict of interest.

\section{REFERENCES}

1. van der Maas PJ, Pijnenborg $L$ and van Delden JJ. Changes in Dutch opinions on active euthanasia, 1966 through 1991.JAMA 1995; 273: 1411-1414.

2. Rietjens JA, van der Heide A, Onwuteaka-Philipsen BD, et al. A comparison of attitudes towards end-of-life decisions: survey among the Dutch general public and physicians. Soc Sci Med 2005; 61: 1723-1732.

3. Strauss AL and Corbin J. Basics of qualitative research: techniques and procedures for developing grounded theory. Thousand Oaks, California: Sage, 1998.

4. Rietjens JA, van Tol DG, Schermer M, et al. Judgement of suffering in the case of a euthanasia request in the Netherlands. J Med Ethics 2009; 35: 502-507.

5. van Tol D, Rietjens $\mathrm{J}$ and van der Heide A. Judgment of unbearable suffering and willingness to grant a euthanasia request by Dutch general practitioners. Health Policy 2010; 97: 166-172.

6. de Boer ME, Droes RM, Jonker C, et al. Advance directives for euthanasia in dementia: do law-based opportunities lead to more euthanasia? Health Policy 2010; 98: 256-262.

7. Rurup ML, Pasman HR and Onwuteaka-Philipsen BD. [Advance euthanasia directives in dementia rarely carried out. Qualitative study in physicians and patients.]Euthanasieverklaringen bij dementie. Kwalitatief onderzoek onder artsen en patienten. Ned Tijdschr Geneeskd 2010; 154: A1273.

8. Rurup ML, Onwuteaka-Philipsen BD, Pasman HR, et al. Attitudes of physicians, nurses and relatives towards end-oflife decisions concerning nursing home patients with dementia. Patient Educ Couns 2006; 61: 372-380.

9. van Marwijk H, Haverkate I, van Royen P, et al. Impact of euthanasia on primary care physicians in the Netherlands. Palliat Med 2007; 21: 609-614.

10. Cohen J, Marcoux I, Bilsen J, et al. Trends in acceptance of euthanasia among the general public in 12 European countries (1981-1999). Eur J Public Health 2006; 16: 663669.

11. Schuklenk U, van Delden JJ, Downie J, et al. End-of-life decision-making in Canada: the report by the Royal Society of Canada expert panel on end-of-life decision-making. Bioethics 2011; 25 (Suppl 1): 1-73.

12. van Holsteyn $\mathrm{J}$ and Trappenburg $\mathrm{M}$. The quest for limits. Law and public opinion on euthanasia in the Netherlands. In: Klijn A, Otlowski M, Trappenburg M, eds Regulating physician-negotiated death, boek uitgave van Recht der Werkelijkheid, 2001, 109-128.

13. Verpoort C, Gastmans C, De Bal N, et al. Nurses' attitudes to euthanasia: a review of the literature. Nurs Ethics 2004; 11: 349-365. 
Kouwenhoven, P.S.C., Raijmakers, N.J.H., Delden, J.J.M. van, Rietjens, J.A.C., Schermer, M.H.N., Thiel, G.J.M.W. van, Trappenburg, M.J., Vathorst, S. van de, Vegt, B.J. van der, Vezzeni, 7 C., Weyers, H., Tol, D.G. van, Heide, A. van der. Opinions of health care professionals and the public after eight years of euthanasia legislation in the Netherlands: a mixed methods approach. Palliative Medicine: 2013, 27(3), 273-280

14. Gielen J, Van Den Branden S and Broeckaert B. Attitudes of European physicians toward euthanasia and physicianassisted suicide: a review of the recent literature. J Palliat Care 2008; 24: 173-184.

15. Peretti-Watel P, Bendiane MK, Pegliasco H, et al. Doctors' opinions on euthanasia, end of life care, and doctor-patient communication: telephone survey in France. BMJ 2003; 327: 595-596.

16. Silvoniemi M, Vasankari T, Vahlberg T, et al. Physicians' attitudes towards euthanasia in Finland: would training in palliative care make a difference? Palliat Med 2010; 24: 744-746.

17. Parpa E, Mystakidou K, Tsilika E, et al. Attitudes of health care professionals, relatives of advanced cancer patients and public towards euthanasia and physician assisted suicide. Health Policy 2010; 97: 160-165.

18. Turla A, Ozkara E, Ozkanli C, et al. Health professionals' attitude toward euthanasia: a cross-sectional study from Turkey. Omega - Journal of Death and Dying (Westport) 2006; 54: 135-145.

19. Yun $\mathrm{YH}$, Han $\mathrm{KH}$, Park S, et al. Attitudes of cancer patients, family caregivers, oncologists and members of the general public toward critical interventions at the end of life of terminally ill patients. Can Med Assoc J 2011; 183: E673-E679.

20. Quebec specialists support legalizing euthanasia. Agnes Reid Global Monitor, http://www.angus-reid.com/ (2011, accessed July 2011).

21. Bachmann LM, Muhleisen A, Bock A, et al. Vignette studies of medical choice and judgement to study caregivers' medical decision behaviour: systematic review. BMC Med Res Methodol 2008; 8: 50.

22. Vayda E, Mindell WR, Mueller CB, et al. Measuring surgical decision-making with hypothetical cases. Can Med Assoc J 1982; 127: 287-290. 
Kouwenhoven, P.S.C., Raijmakers, N.J.H., Delden, J.J.M. van, Rietjens, J.A.C., Schermer, M.H.N., Thiel, G.J.M.W. van, Trappenburg, M.J., Vathorst, S. van de, Vegt, B.J. van der, Vezzeni, C., Weyers, H., Tol, D.G. van, Heide, A. van der. Opinions of health care professionals and the ive public after eight years of euthanasia legislation in the Netherlands: a mixed methods approach. Palliative Medicine: 2013, 27(3), 273-280

\section{TABLES AND \\ BOXES}

Box I. Vignettes of patients requesting euthanasia or physician-assisted suicide: different ways of suffering.*

I (a) Mrs de Jong (60 years old) has breast cancer with metastases. Despite undergoing several treatments, her disease is no longer curable. She is in severe pain that cannot be sufficiently relieved. In addition, she dislikes the feeling of loss of control that she experiences. In her working days, she always felt in control. She indicates that she cannot take it anymore. She asks her general practitioner for physician-assisted suicide. The general practitioner decides to honour her request and performs physician-assisted suicide.

I(b) Mrs de Jong (60 years old) has breast cancer with metastases. Despite undergoing several treatments, her disease is no longer curable. She has no physical symptoms at the moment She dislikes the feeling of loss of control that she experiences. In her working days, she always felt in control. She indicates that she cannot take it anymore. She repeatedly asks her general practitioner for physician-assisted suicide. The general practitioner decides to honour her request and performs physician-assisted suicide.

I(c) Mr de Bruyn is 86 years old. He used to be a professor at the university. He enjoyed his life at that time. He never married and has no children. Now he has grown old, many of his friends have died. He often feels lonely. He is in good physical and mental condition. Though Mr de Bruyn is aware that he could live for many years he fears this. He would rather be dead and has told his general practitioner this several times. Mr de Bruyn repeatedly asks his general practitioner for physician-assisted suicide. The general practitioner decides to honour his request and performs physician-assisted suicide.**

I(d) Mrs Langezaal is middle-aged. She is physically well, but mentally ill. She has been suffering from severe depression for years and her psychiatrist's treatment has not worked. She regularly tells her physicians that she wants to die. She already has had one unsuccessful suicide attempt. Mrs Langezaal visits her psychiatrist and repeatedly asks for physician-assisted suicide. The psychiatrist decides to honour her request and performs physician-assisted suicide.

I (e) Mrs de Koning is 65 years old. She suffers from early dementia and sometimes she is forgetul. She fears what is to come, the progressive loss of memory and the moment she will not recognise her surroundings anymore. Her own mother suffered from severe dementia and she absolutely doesn't want to experience this process herself. Mrs de Koning repeatedly asks her general practitioner for physician-assisted suicide. The general practitioner decides to honour her request and performs physician-assisted suicide.

I(f) Mr Smit is 62 years old and suffering from dementia. He doesn't recognise his wife and children anymore, refuses to eat and withdraws into himself more and more. It is no longer possible to communicate with him about his treatment. Shortly before he became demented, he drafted an advance directive with a euthanasia request in case of dementia. His family agrees. The physician decides to honour his patient's advanced directive and performs euthanasia.

"For the general public, these vignettes were the same in contents, but slightly adapted in language in order to be understandable for this group of respondents.

-I (c): Not in accordance with the Dutch Euthanasia Act (2002). 
Kouwenhoven, P.S.C., Raijmakers, N.J.H., Delden, J.J.M. van, Rietjens, J.A.C., Schermer, M.H.N., Thiel, G.J.M.W. van, Trappenburg, M.J., Vathorst, S. van de, Vegt, B.J. van der, Vezzeni, 7 C., Weyers, H., Tol, D.G. van, Heide, A. van der. Opinions of health care professionals and the ive public after eight years of euthanasia legislation in the Netherlands: a mixed methods approach. Palliative Medicine: 2013, 27(3), 273-280

Table I. Background characteristics of respondents.

\begin{tabular}{|c|c|c|c|}
\hline & $\begin{array}{l}\text { Physicians* } \\
(n=793) \%\end{array}$ & $\begin{array}{l}\text { Nurses } \\
(n=\mid 243) \%\end{array}$ & $\begin{array}{l}\text { General public } \\
(n=1960) \%\end{array}$ \\
\hline \multicolumn{4}{|l|}{ Age } \\
\hline Mean \pm SD & $51 \pm 8$ & $44 \pm 11$ & $53 \pm 15$ \\
\hline \multicolumn{4}{|l|}{ Gender } \\
\hline Male & 65 & 10 & 54 \\
\hline Female & 35 & 90 & 46 \\
\hline \multicolumn{4}{|l|}{ Education 1,2} \\
\hline Low & n.a. & n.a. & 32 \\
\hline Middle & n.a. & 19 & 29 \\
\hline High & 100 & 81 & 39 \\
\hline \multicolumn{4}{|c|}{ Experience with euthanasia request ${ }^{3}$} \\
\hline Yes & 71 & 64 & 14 \\
\hline No & 29 & 36 & 86 \\
\hline \multicolumn{4}{|l|}{ Care setting } \\
\hline Hospital care & 39 & 41 & n.a. \\
\hline Home care & 51 & 23 & n.a. \\
\hline Nursing home care & 10 & 28 & n.a. \\
\hline \multicolumn{4}{|c|}{ Years of working experience 4} \\
\hline $2-5$ years & 6 & 15 & n.a. \\
\hline $5-10$ years & 16 & 13 & n.a. \\
\hline$>10$ years & 78 & 72 & n.a. \\
\hline \multicolumn{4}{|c|}{ Attitude towards euthanasia and physician-assisted suicide } \\
\hline Liberal & 45 & 59 & - \\
\hline Reserved & 48 & 27 & - \\
\hline Aqainst & 7 & 14 & 5 \\
\hline
\end{tabular}

na: not applicable; SD: standard deviation.

*Weighted percentages.

'Low=level I-3 according to International Standard Chssification of Education (ISCED) (primary school, lower secondary general education, lower vocational education), middle= level 4 according to ISCED (intermedlate vocational or higher secondary general education), high= level 5-7 according to ISCED (higher vocational education or university).

2Nurses: middle=assistant nurse, high=registered nurse

JExperience with a patient's (for physiclans and nurses) or relative's (for the general public) actual request in the last five years

4Physiclans: mean $\pm S D=19 \pm 9$. 
Kouwenhoven, P.S.C., Raijmakers, N.J.H., Delden, J.J.M. van, Rietjens, J.A.C., Schermer, M.H.N., Thiel, G.J.M.W. van, Trappenburg, M.J., Vathorst, S. van de, Vegt, B.J. van der, Vezzeni, 7 C., Weyers, H., Tol, D.G. van, Heide, A. van der. Opinions of health care professionals and the ive public after eight years of euthanasia legislation in the Netherlands: a mixed methods approach. Palliative Medicine: 2013, 27(3), 273-280

Box 2. Examples of responses.

\begin{tabular}{|c|c|}
\hline $\begin{array}{l}\text { 2. I:Arguments } \\
\text { for the possibility } \\
\text { of euthanasia: } \\
\text { 'end suffering' and } \\
\text { 'autonomy' }\end{array}$ & $\begin{array}{l}\text { 'Anyhow, I think it is very good we have a euthanasia law in the Netherlands. Because I think } \\
\text { every person that really suffers unbearably should have the right to end his life.' (member of the } \\
\text { general public) } \\
\text { 'I think we have a very correct legal system in the Netherlands, which clearly prescribes what } \\
\text { is allowed and what is not. So we have said, we highly esteem the autonomy of the patient If } \\
\text { someone wishes to end his life, and there is unbearable suffering, there is careful deliberation } \\
\text { and there is freedom, then I think that we, as doctors, can cooperate with that' (physician with } \\
\text { experience with euthanasia) }\end{array}$ \\
\hline $\begin{array}{l}\text { 2.2: Defense } \\
\text { against } \\
\text { misinformed } \\
\text { critics }\end{array}$ & $\begin{array}{l}\text { 'People from outside the Netherlands seem to think that it is just a phone call to the doctor who } \\
\text { prescribes a recipe for a lethal drug in order to put you out of this world. Well, that is not how } \\
\text { it is. There are many conversations and checks before a wish is granted. So before something like } \\
\text { that is done, there have been a lot of control moments, in order to make sure it is all done in a } \\
\text { careful manner. So it is not easily done.' (member of the general public) } \\
\text { 'I would say it happens in the most careful way, and always in a situation of endless suffering. } \\
\text { But doctors are really not eager to perform euthanasia. It is not part of everyday practice, but } \\
\text { it may be an ultimate act in a situation of necessity, which is never decided alone but always in } \\
\text { consultation of another doctor. The Netherlands is not a country in which you can just say'I don't } \\
\text { want to go on anymore, and I step out'.' (nurse) }\end{array}$ \\
\hline $\begin{array}{l}\text { 2.3: Euthanasia } \\
\text { Act as a safeguard } \\
\text { for careful and }\end{array}$ & $\begin{array}{l}\text { 'It is not as easy as one may think. There have to be very good reasons. There have to be two } \\
\text { doctors. Only if they are both convinced that this euthanasia is really what the person wants, and } \\
\text { if they think the suffering becomes unbearable. Only then you can perform euthanasia.' (nurse) }\end{array}$ \\
\hline $\begin{array}{l}\text { transparent } \\
\text { practice }\end{array}$ & $\begin{array}{l}\text { 'I have some difficulties with it (euthanasia). Yet it is good such a law exists and that one should } \\
\text { follow strict criteria. But actually I would want that things like euthanasia and abortion did not } \\
\text { happen.' (nurse) } \\
\text { 'You still perform a criminal act and you can go to jail for it. I think there is a strong urge for } \\
\text { doctors to act in a careful manner. There is a procedure that has to be followed. And it has to } \\
\text { be reported. I think it is an honest procedure, I don't have problems with that' (physician who } \\
\text { refuses to perform euthanasia himself) }\end{array}$ \\
\hline $\begin{array}{l}\text { 2.4: Legal rules as } \\
\text { a 'helping hand' } \\
\text { and as a 'shield' }\end{array}$ & $\begin{array}{l}\text { 'I think the law is good. It is a helping hand, because listen, you do end some one's life. The law is } \\
\text { not without a purpose, it was constructed very carefully. In such a way that you always have to act } \\
\text { very carefully and I think that is good. It is a highly demanding process. For the patient, but also } \\
\text { for the doctor'. (physician with experience with euthanasia) } \\
\text { 'Sometimes you come in the ward and then, all of a sudden, you get a request to perform } \\
\text { euthanasia. Then I say 'that is not how it works'. Unless it is a very exceptional situation. But then } \\
\text { you may use that argument and tell the patient 'I have to protect myself as well. I have to fulfill the } \\
\text { due care requirements, it is not so easily done'. So in that way I am happy with the rules. It may } \\
\text { help to keep off patients who think too easy about it. Personally I may not have huge difficulties } \\
\text { with it, but I do not think it should ever become a routine. I won't go that far. So I agree with } \\
\text { those criteria of due care, they are very logical to me.' (physician with experience with euthanasia) }\end{array}$ \\
\hline
\end{tabular}

Table 2. Opinions on euthanasia and physician-assisted suicide.

\begin{tabular}{|c|c|c|c|}
\hline & $\begin{array}{l}\text { Physicians* } \\
n=793(\%)\end{array}$ & $\begin{array}{l}\text { Nurses } \\
n=1243(\%)\end{array}$ & $\begin{array}{l}\text { General public } \\
n=1960(\%)\end{array}$ \\
\hline \multicolumn{4}{|c|}{ In my opinion everybody should have a right to get euthanasia or physician-assisted suicide when he or she wants. } \\
\hline (Totally) agree & 28 & 45 & 57 \\
\hline (Totally) disagree** & 56 & 36 & 23 \\
\hline Neutral & 14 & 19 & 20 \\
\hline \multicolumn{4}{|c|}{$\begin{array}{l}\text { In my opinion a physician is only allowed to perform euthanasia or physician-assisted suicide in persons with a life expectancy of a } \\
\text { few weeks. }\end{array}$} \\
\hline (Totally) agree & 16 & 18 & 27 \\
\hline (Totally) disagree*t* & 71 & 64 & 48 \\
\hline Neutral & 12 & 19 & 25 \\
\hline \multicolumn{4}{|c|}{ In my opinion euthanasia and physician-assisted suicide should only be allowed to be performed at explicit patient request } \\
\hline (Totally) agree** & 88 & 77 & 64 \\
\hline (Totally) disagree & 7 & 14 & 16 \\
\hline Neutral & 5 & 9 & 21 \\
\hline
\end{tabular}

"Weighted percentages.

-In accordance with the Dutch Euthanasia Act (2002). 
Kouwenhoven, P.S.C., Raijmakers, N.J.H., Delden, J.J.M. van, Rietjens, J.A.C., Schermer, M.H.N., Thiel, G.J.M.W. van, Trappenburg, M.J., Vathorst, S. van de, Vegt, B.J. van der, Vezzeni, 7 C., Weyers, H., Tol, D.G. van, Heide, A. van der. Opinions of health care professionals and the public after eight years of euthanasia legislation in the Netherlands: a mixed methods approach. Palliative Medicine: 2013, 27(3), 273-280

Table 3. Opinions on euthanasia and physician-assisted suicide: agreement with the physician's act in different cases of suffering. See Box I for corresponding vignettes.

\begin{tabular}{|c|c|c|c|}
\hline & Yes (\%) & No (\%) & $\begin{array}{l}\text { I don't } \\
\text { know(\%) }\end{array}$ \\
\hline \multicolumn{4}{|c|}{ (a) Cancer with loss of control and severe pain } \\
\hline Physicians* $n=156$ & 77 & 17 & 7 \\
\hline Nurses $n=254$ & 49 & 38 & 13 \\
\hline General public $n=421$ & 65 & 15 & 19 \\
\hline \multicolumn{4}{|c|}{$\begin{array}{l}\text { (b) Cancer with loss of control, without physical } \\
\text { symptoms }\end{array}$} \\
\hline Physicians* $n=|6|$ & 37 & 45 & 19 \\
\hline Nurses $n=245$ & 36 & 48 & 15 \\
\hline General public $n=393$ & 39 & 44 & 17 \\
\hline \multicolumn{4}{|c|}{ (c) Old age and tired of living** } \\
\hline Physicians* $n=143$ & 18 & 66 & 16 \\
\hline Nurses $n=245$ & 19 & 64 & 18 \\
\hline \multicolumn{4}{|l|}{ (d) Severe depression } \\
\hline Physicians* $n=173$ & 35 & 39 & 26 \\
\hline Nurses $n=253$ & 36 & 46 & 19 \\
\hline General public $n=380$ & 28 & 52 & 20 \\
\hline \multicolumn{4}{|l|}{ (e) Early dementia } \\
\hline Physicians* $n=156$ & 28 & 53 & 17 \\
\hline Nurses $n=246$ & 31 & 49 & 20 \\
\hline General public $n=388$ & 24 & 60 & 16 \\
\hline \multicolumn{4}{|c|}{$\begin{array}{l}\text { (f) Advanced dementia and written advance directive } \\
\text { for euthanasia }\end{array}$} \\
\hline Physicians* $n=197$ & 33 & 56 & 11 \\
\hline Nurses $n=316$ & 58 & 29 & 13 \\
\hline General public $n=472$ & 77 & 14 & 9 \\
\hline
\end{tabular}

Weighted percentages.

*Not in accordance with the Dutch Euthanasia Act (2002). 